\title{
Proposed Service System Improvement for Regional Bank's Mobile Banking Application using Service Science Perspective
}

\author{
Aditya Pratama and Santi Novani
}

\section{ABSTRACT}

\begin{abstract}
Mobile banking application provides easy banking services wherever and whenever only using the internet and mobile devices. Today one of the regional banks in Indonesia struggles to encourage the customer to install and use the mobile banking application for banking services because most customers are difficult to understand their mobile baking system and want an easier method to access the services. For this reason, the management suggests increasing the marketing focus towards its current customer for mobile banking and improving the service system to be easier to use and accommodate the user's current need. This research aims to help improve their service system using a service science perspective. Based on the service science framework, the author has analysed the provider and customer perspectives. Then, the root causes analysis identifies all problems, gaps, and customer needs. After conducting the analysis, the problem was found from lack of collaboration, the registration system to create account not optimal, and mobile banking activation system is not optimal. After implementing the value co-creation and orchestration process, the author proposed service system improvement using service blueprint and value blueprint.
\end{abstract}

Keywords: Mobile banking, service blueprint, Service science, Service system, value blueprint, Value co-creation and Orchestration.

\author{
Submitted : August 25, 2021 \\ Published : September 16, 2021 \\ ISSN: $2507-1076$ \\ DOI: $10.24018 /$ ejbmr.2021.6.5.1061 \\ Aditya Pratama* \\ Bandung Institute of Technology, \\ Bandung, West Java, Indonesia. \\ (e-mail: aditya_pratama@sbm-itb.ac.id) \\ Santi Novani \\ Bandung Institute of Technology, \\ Bandung, West Java, Indonesia. \\ (e-mail: snovani@sbm-itb.ac.id) \\ *Corresponding Author
}

\section{INTRODUCTION}

The coronavirus outbreak has shaken the world at the end of 2019 in Wuhan, China, and after a few months, it became a global pandemic [1]. Indonesia first officially recognize the Covid-19 case is in March 2020, and after the first case, the government imposed the closure of various institutions [2]. A few weeks after the first incident, Covid-19 patients continued to increase in different regions in Indonesia. All social distancing and social restrictions policies from the government ranging from large-scale social restriction or 'Pembatasan Sosial Berskala Besar' (PSBB), PSBB transition, micro lockdown, application of restrictions on community activities or 'Pemberlakuan Pembatasan Kegiatan Masyarakat' (PPKM), and lastly PPKM micro, causing limited public access to daily needs due to work from home policy and recommendations to stay at home and closing of several sectors [3]. However, after a few times, the government decided to lower the restriction policy, including the banking sector. The offline banking services are only limited to serve $25 \%$ of the maximum capacity to minimize the service contact, and people tend to not go to the bank because of fear of Covid-19 [4]. Even so, there is still an option to use online banking services, especially mobile banking services. This usage is also supported by the number of internet users in Indonesia during the pandemic increased, and most were accessed through mobile devices [5], [6].

Internet users in Indonesia increased by $15.5 \%$ in a year from 2019 to 2020 . The mobile internet device became the most significant percentage of $96.4 \%$ [5], and this illustrates that almost all Indonesians access the internet through mobile devices. According to the survey, the number of digital consumers in Southeast Asia, including Indonesia, in 2020 is estimated at 310 million people [7]. This number has increased from 2019 by approximately 30 million people and is predicted to reach 340 million people in 2025 [7]. These are the effect of social distancing and social restrictions policy in Indonesia. Most people choose online services to meet their daily needs and minimize physical contact; one of them is mobile banking services [8]. Mobile banking is an internet-based digital banking service that can be accessed whenever and wherever through a mobile application, which can fulfil banking services ranging from account opening, saving, digital payments, funds transfer, and many more [9], [10]. As mentioned before, pandemic conditions change people's banking services from offline banking or ATM services to online banking services, significantly accelerating mobile banking services [8]. From these conditions, mobile banking from one of the regional banks in Indonesia must innovate and improve online banking services or mobile banking to meet customer's needs to compete with other banks that have mobile banking features. In addition, competition with other banks in getting new customers from online banking will be tighter [11]. Therefore, the urgency in innovating or improving online banking system services, especially mobile banking, is critical and in immediate time. 
One of the regional banks in Indonesia wants to improve and innovate its mobile banking. However, the regional bank management struggles to encourage the customer to install and use the mobile banking application for banking services. The reason is that most of their customers are mainly difficult to understand their mobile banking system and want an easier method to access the services. For this reason, the management suggests increasing the marketing focus towards its current customer for their mobile banking and improving the service system to be easier to use and accommodate the user's current need. In this research, the author focuses only on improving the service system to solve the problem. To help improve the services system on mobile banking services, the author uses a scientific approach based on service science to improve the services. Therefore, this research aimed to identify the gap in the service system between the desire of regional bank customers and the service provided in their mobile banking service and propose alternative solutions to improve the service system of the regional bank's mobile banking service.

\section{LITERATURE REVIEW}

\section{A. Service Science}

Service Science, also known as Service Science, Management, Engineering, and Design (SSMED), is a new interdisciplinary approach to studying, improving, creating, and innovating in service and service systems [12], [13]. On the topic of Service Science, Engineering and Management (SSEM), there is an understanding that SSEM is a multidisciplinary approach to managing and designing value co-creation of a merit system. This approach develops a holistic view of a system into a comprehensive service system, beginning to the end while focusing on the customer [14]. Service science is referred to as the short term for SSME, that the words are often used interchangeably [15].

In addition, Service science is the study of service systems to create a basis for systematic service innovation. Service systems are value-co-creation configurations of people, technology, value propositions connecting internal and external service systems, and shared information (e.g., language, laws, measures, and methods). It combines organization and human understanding with business and technological understanding to classify and describe many types of service systems that exist and how service systems interact and evolve to co-create value. The goal is to apply scientific knowledge to advance our ability to design, improve, and scale service systems [16].

\section{B. Model Value Co-creation Process}

The four-phase value co-creation process model is a model for opening the concept of value co-creation. Meanwhile, the value co-creation interaction is an active, creative, and social process based on the provider and customer collaboration that the provider initiates to generate value for customers. Although the provider begins it, it is still a form of collaborative creativity of customers and providers that enhances knowledge-acquisition processes by involving the customer in creating meaning and significance. Those fourphase model from co-experience, co-definition, co-elevation, and co-development [12], [17]-[21]:
Co-experience of service is when participating in the collaborative value co-creation process, customers and providers may not know each other's capabilities and expectations. Hence, rather than reducing the gap between the needs and seeds, the provider and customer may need to share an internal model to co-define a mutual understanding about the service by co-experience.

Co-definition model means that by interacting with each other, the customer and provider may learn about each other's preferences, capabilities, and expectations to co-define and share a standard internal model. Satisfaction for both sides is generated by the co-experience of both side's service and the co-definition of a shared internal model.

Co-elevation of each other is a zigzag-shaped spiral process of customer's expectations and provider's capabilities. Higher expectations of service by the customer lead to higher-quality service and greater social values (needs pull). In turn, high-quality service increases customer expectations level (seeds push).

Co-development of value, on the other hand, we call the latter co-development because it takes notice of the value cocreated by simultaneous collaboration among various entities. Co-development of service value is usually carried out in customer's evaluation and assessing the value and providers learning from customer responses.

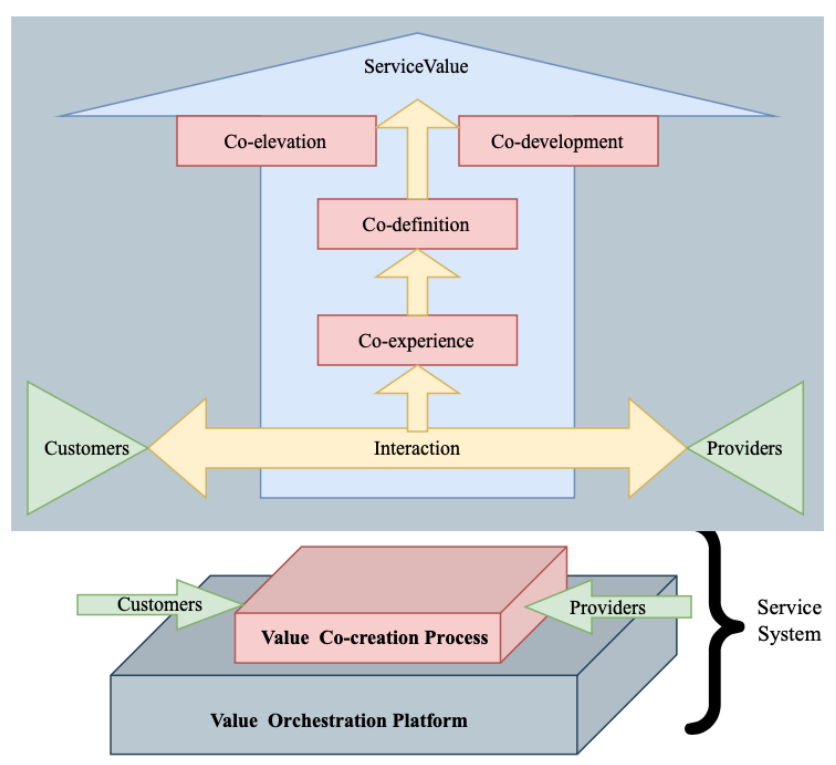

Fig. 1. Research Framework.

The model above directly describes service as a value cocreation interaction between customers and providers. It identifies four phases in the process, as shown in Fig. 1. The first two phases, co-experience, and co-definition are relatively short-range concepts for defining service appreciation. The last two phases, co-elevation, and codevelopment refer to the long-range activities essential for service innovation [17].

\section{Model Value Orchestration Platform}

In the model value orchestration platform, some values will be used. The first is the value involvement strategy. Here, the platform orchestrator is mainly concerned with getting appropriate customers and providers "on board" the platform and liven up interactions between customers and providers. 
Then the value curation strategy. Although the strategy for the involvement of customers and providers targeted how to draw customers and providers to the platform, value curation is vital for the platform to encourage customers and providers to co-elevate and co-develop. Lastly, value empowerment strategy. Empowerment is how a platform empowers customers and providers, so each side finds the other attractive and motivated to interact. Customers are empowered by lifting their aspiration level, while their service capability empowers providers [17], [20], [21].

These strategies above, from involvement, curation, and empowerment, are closely tied to the different value cocreation process stages. Involvement strategy focuses on coexperience and co-definition stages, whereas empowerment focuses directly on co-elevation and co-development stages. Table I illustrates relevant actions for each strategy and value co-creation process of a value orchestration platform.

\begin{tabular}{|c|c|c|c|}
\hline & & \multicolumn{2}{|c|}{$\begin{array}{l}\text { Value Co-creation Process } \\
\end{array}$} \\
\hline & & Co-experience $\quad$ Co-definition & Co-development \\
\hline \multirow{3}{*}{$\begin{array}{c}\text { Value } \\
\text { Orchestration } \\
\text { Strategies }\end{array}$} & Involvement & $\begin{array}{l}\text { Getting on co-experience and } \\
\text { co-definition process }\end{array}$ & \\
\hline & Curation & & $\begin{array}{l}\text { Re-examining content and meaning of existing } \\
\text { information and putting a new interpretation }\end{array}$ \\
\hline & Empowerment & & Promoting co-elevation and co-development process \\
\hline
\end{tabular}

\section{Service System and Service Design}

A service system is a work system that produces services; meanwhile, a work system is a system in which people or machines use information, technology, and other resources to create products/services for internal or external customers. The participants in the service system are the service provider. Still, sometimes customers can be participants because they often do some work within the service system [22], [23].

Service design is not a precise statement about how a service system will operate. Instead, it is an idealized summary of a service system. Service design may or may not include service interactions, contrary to typical beliefs that the core of service occurs in service interactions. The actual operation of a service system and the value facilitation for customers may differ from its design in various ways. Sources of divergence include behavioural discretion, incomplete specifications, unexpected exceptions, other contingencies, workarounds, adaptations, and other conditions or events [22].

\section{E. Service Blueprint}

A service blueprint is a picture or map which describes the customer experience and the service system. By involving different people in providing the service, they can understand it objectively, regardless of their roles or points of view. Blueprints are handy at the design stage of service development, manage service operation and improvement. A service blueprint visually displays the service by simultaneously portraying service delivery, customer contact points, the roles of customers and employees, and the visible elements of the service. It provides a way to break a service down into its logical components and depict the steps or tasks in the process, how the tasks are executed, and the evidence of service as the customer experiences it [24], [25].

\section{F. Value Blueprint}

A value blueprint is a value-centered variation on service blueprinting that links customer actions to specific things customers value about a particular service system or value constellation. It combines concepts such as customer and provider responsibilities, service instances, service interactions, and frontstage and backstage. Value capture for both customers and providers can occur during negotiation, set-up, service request, fulfilment, and follow-up phases. It can extend far beyond the timeframe of a specific service instance. Value blueprints contain information that is useful for service design. It encourages the service designer to focus on how the service provider promotes value creation and how the customer creates value [22].

\section{G. Fault Tree Analysis}

A fault tree (FT) is a graphical diagram that utilizes logic gates to model the numerous combinations of faults, failures, errors, and ordinary events involved that cause an undesired event (UE), and this was used to do fault tree analysis (FTA). FTA is a system analysis that uses FT as the root-cause investigative methodology. This system specifies combinations of events and conditions that lead to the occurrence of a specified UE. Using FTA is for system improvement and use analytical processes in developing and evaluating a system. Thus, sometimes it is referred to as a Logic Diagram Analysis. FTA elaborates the logical fault paths through the system that emanates from all the possible root causes; hence the analysis is deductive from the general problem to the detailed causal factors. The FT of a system graphically characterizes the combinations of elemental failures that can yield the top UE [26], [27]. As shown in Table II, FTA uses symbols to outline various events and their relationships in a process.

\section{RESEARCH METHODOLOGY}

Based on the literature reviews, the research framework used in this research is shown in Fig. 1, which understands provider and customer perspectives to create value. This research data collection uses the qualitative method because it is the most appropriate data collection. It is in interviews with customers and providers, observations of the existing service system, and secondary data. The primary data will mainly be obtained by interviewing the regional bank's mobile banking management and the customer, then supported by the author's direct observation. In addition, the authors did a literature review on different academic journal data sources and company annual reports to acquire secondary data, such as the requirement for literature and empirical methodologies. The author conducts specific subjects to interview. Those subjects are representing both 
form provider and customer of regional bank's mobile banking.

\begin{tabular}{|c|c|}
\hline \multicolumn{2}{|r|}{ TABLE II: LIST OF FTA SYMBOLS } \\
\hline Gate Symbols & Description \\
\hline And & $\begin{array}{l}\text { And gate means a condition in which all events } \\
\text { displayed below the gate (input gate) must be } \\
\text { fulfilled so that the event shown above the gate } \\
\text { (output event) occurs. Simply, the output event will } \\
\text { only happen if all the input events exist } \\
\text { simultaneously. }\end{array}$ \\
\hline OR & $\begin{array}{l}\text { Or gate represents a situation in which the event } \\
\text { shown above the gate (output event) will appear if } \\
\text { any of the events shown below the gate (input gate) } \\
\text { are performed. Simply, the event can occur although } \\
\text { only one or any combination of the input events } \\
\text { exists. }\end{array}$ \\
\hline Event Symbols & Description \\
\hline EVENT & $\begin{array}{l}\text { The rectangle is the leading block for the FT because } \\
\text { it represents the adverse event. It can be found at the } \\
\text { top of the tree and throughout it to indicate further } \\
\text { breaking down events. }\end{array}$ \\
\hline & $\begin{array}{l}\text { A circle shows a base event found on the bottom } \\
\text { tiers of the tree and needs no more development or } \\
\text { breakdown. There are no gates or events below the } \\
\text { base event. }\end{array}$ \\
\hline & $\begin{array}{l}\text { The diamond identifies the terminal event that is } \\
\text { undeveloped. Such an event is not fully developed } \\
\text { due to a lack of information or significance. A fault } \\
\text { tree branch can end with a diamond. }\end{array}$ \\
\hline & $\begin{array}{l}\text { An oval symbol represents certain situations that can } \\
\text { only occur if certain circumstances happen. }\end{array}$ \\
\hline TRA & $\begin{array}{l}\text { The triangle signifies the transfer of a fault tree } \\
\text { branch to another location in the tree. It connects to } \\
\text { the tree with an arrow. Everything that is shown } \\
\text { under the connection point is transferred to another } \\
\text { area of the tree. }\end{array}$ \\
\hline
\end{tabular}

When planning new solutions for a selected context, all design analysis should begin with understanding the corporate and the sort of service you're designing for [28]. The first subject is the provider, who is the regional bank's mobile banking Management representative. Then, the customer side will be divided into three categories because this service is delivered specifically. First is the regional bank's mobile banking current user with 15 interviewees. Regional bank customers with a bank account but not yet using mobile banking with two interviewees, and the last is people who want to open a bank account with eight interviewees.

The author uses the research design in Fig. 2 as guidance and flow of research to find the proposed business solution.

\section{RESEARCH FINDINGS}

\section{A. Business Environment Analysis}

There are so many interactions in the services that make it run before analysing it into a more profound analysis. We look first at the overall service interaction and stakeholder and service ecosystem in regional bank's mobile banking. This analysis comes from author observation through the service and secondary data.

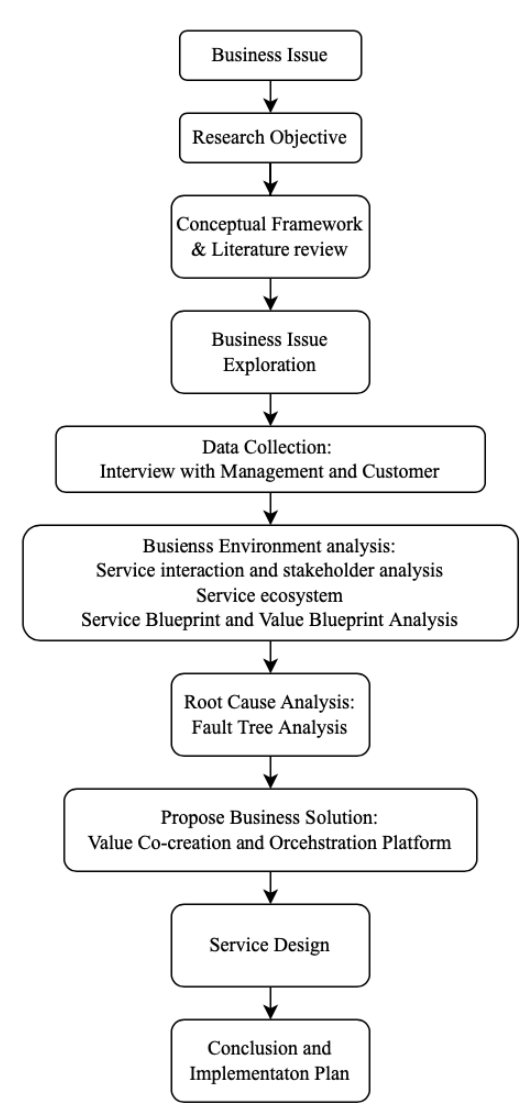

Fig. 2. Research Design.

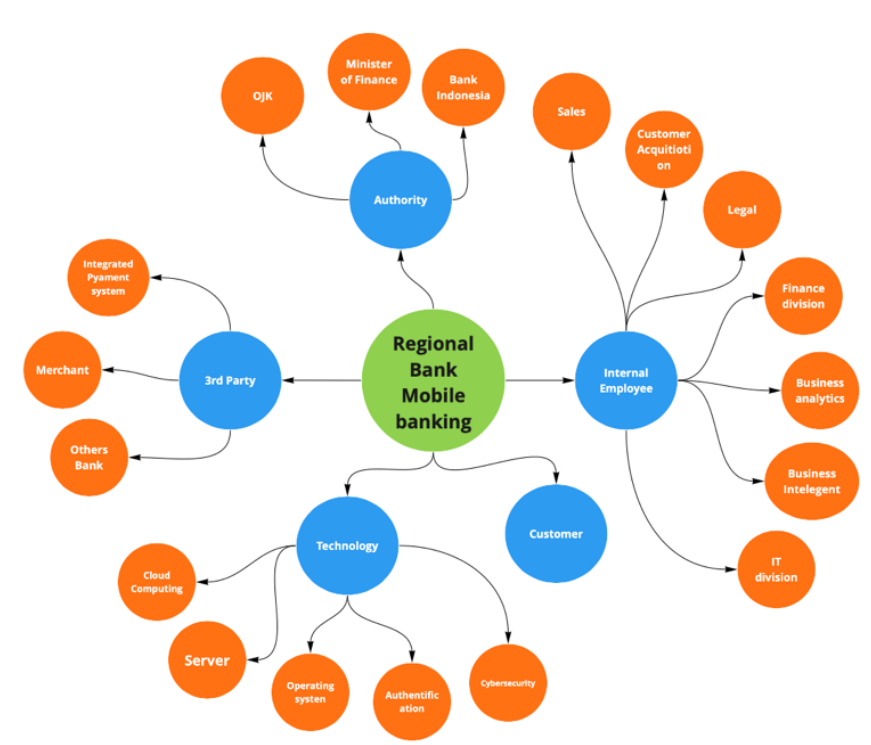

Fig. 3. Service system Interaction.

Regional bank's mobile banking services work together with four mains components to make the service system work. We can see from Fig. 3 from an internal employee that performs the service that contributes to monitoring and evaluation, marketing, and as a service and platform provider.

The authority that contributes to providing law and protection. Customer who is an existing customer of a regional bank and potential new customer generates revenue, database, and feedback. The last is $3^{\text {rd }}$ parties such as merchants and technology provide support infrastructure and collaboration. All four components contribute to the regional bank's mobile banking service system. They also have reason to be here. We know that all the stakeholders above are 
essential to the services, but the most important and we can manage are the customer and internal employee or management.

Regional bank's mobile banking creates or generates earnings by taking a certain commission fee on several transactions. Those are generally caused by customers and partners who use the platform. As shown in Fig 4, this analysis comes from author observation through the service and secondary data.

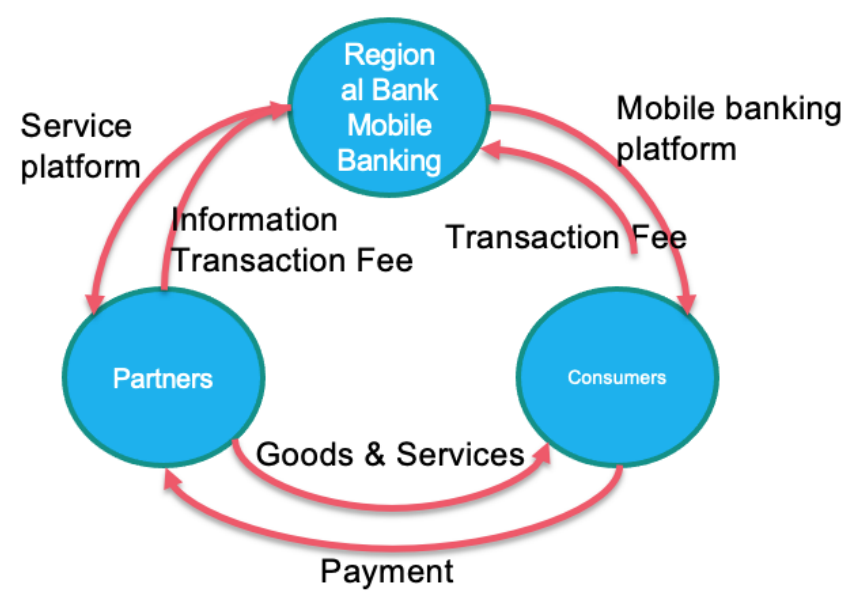

Fig. 4. Service ecosystem.

The three entities of the regional bank's mobile banking ecosystem play a different role from the above service ecosystem, and all are important. Still, the most significant are regional bank's mobile banking and consumer. Because of that, there will be a different approach from the provider and customer.
As mentioned in the research methodology, the interview was conducted. From that interview and the direct observation, the existing service blueprint and value blueprint can be obtained. For the existing service blueprint, we identified seven fail points. There is one uncontrollable fail point which is registration proof, and six are controllable which are online registration form, go to nearest bank office, fill out the form offline, mobile banking activation, verification via OTP and two-step activation for mobile banking. Those fail points come from the registration of bank account and mobile banking. There are no-fail points identify from the log-in system in the service blueprint. Then, from the existing value blueprint, it can be specified there are four activities which are choose the product, customer agreement, fill the formula and insert debit card to ATM that the value has not been delivered yet and seven that have a negative value that are: registration proof; take queue number and wait; show to the CS pdf proof, KTP and NPWP; fill out the form again; signing 4-5 documents; get verification SMS with OTP; and insert the debit card again. Like before, those activities are from registration of bank account and activation of mobile banking. The value-form log-in system has delivered well in the value blueprint.

\section{B. Root Cause Analysis}

Root cause analysis is the process of defining the problem by using structured procedures to determine the root cause of the problem. In conducting the root cause analysis, the author uses the fault tree analysis method. Below is the result of the fault tree analysis from all the data coming from business environment analysis.

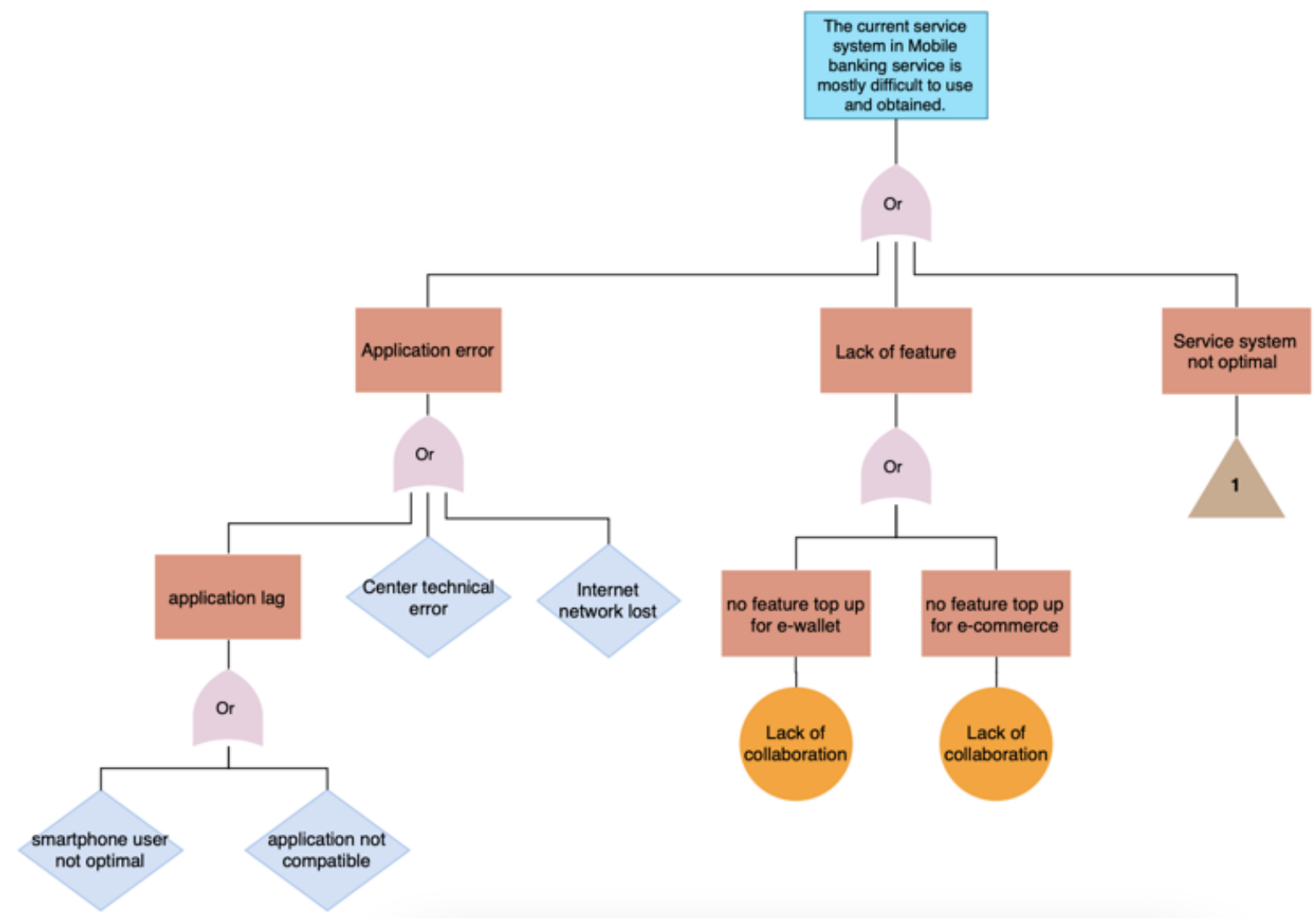

Fig. 5. Fault Tree Analysis Part 1. 


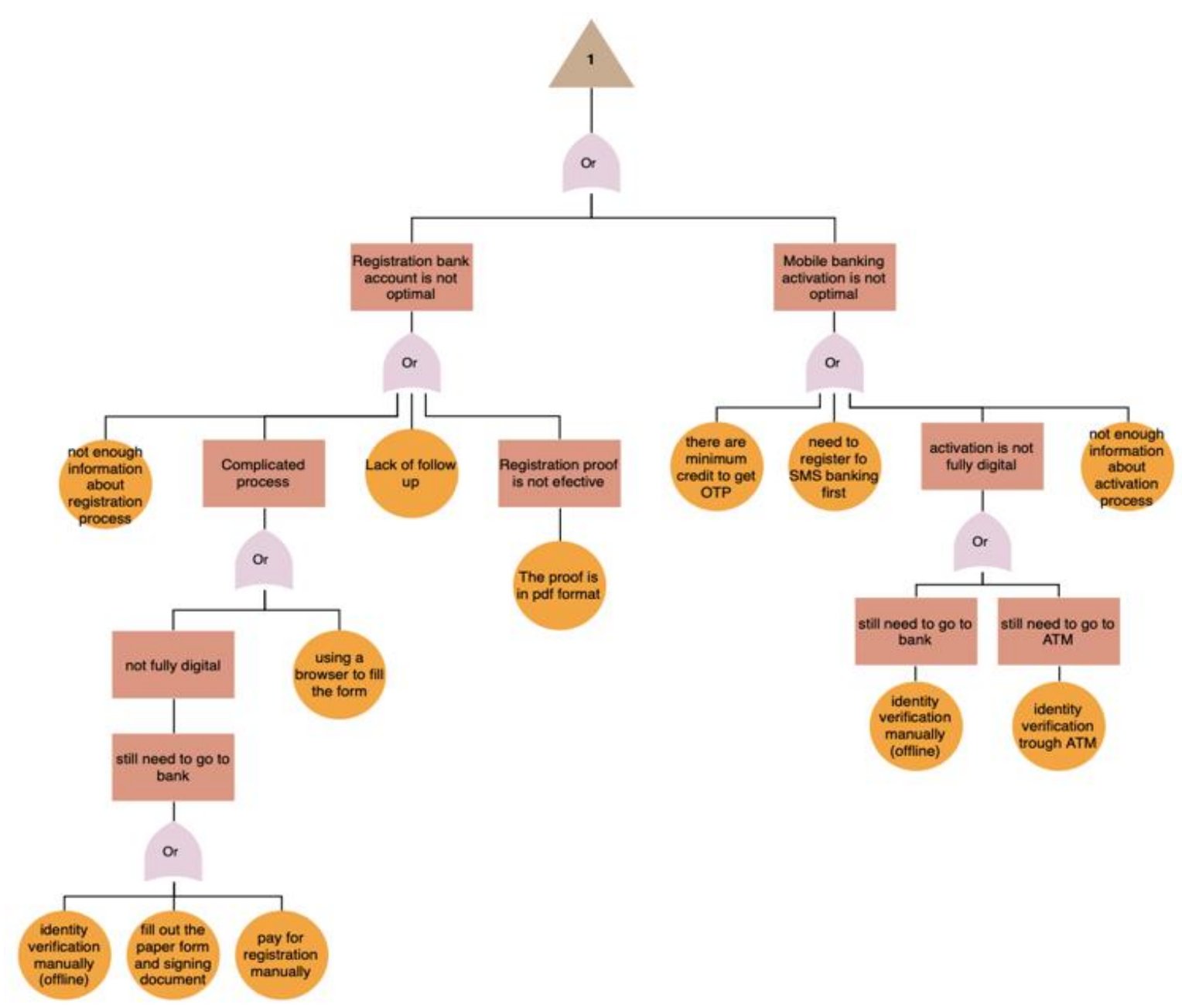

Fig. 6. Fault Tree Analysis Part 2.

From the root cause analysis above in Fig. 5 and 6, there is three intermediates event on the first level contributors. The first event is an application error. At the second level, contributors end with a diamond or undeveloped event because there is no more information, and it is not the scope of the research. Thus, there is no root cause or basic event. The second event in the first level is lack of feature, at the second level contributor all event ends up with diamond or undeveloped event because of no more information. The third event from this level is service system is not optimal. Then the second level is registration bank is not optimal, and the mobile banking activations are not optimal. From this level, there are many basic events or root causes identify which is the circular one. All the eleven root causes come from lack of feature. The registration bank account is not optimal, and the mobile banking activations are not optimal, so that the business solution will focus on those three events.

To conclude, the business issue was identified through the exploration using the service science framework and some literature review. We created the research design that told us what steps, flows, and tools were used. First, we collected the primary data using a qualitative method: an interview from a management perspective and a customer perspective. It resulted in the information of current problem, what they want and what they hope in the future this data will be used to contribute to service blueprint and value blueprint analysis. The service blueprint resulted in understanding the service system and the pain point of the system. The value service blueprint resulted in what value occurred in the service and understand the value that was not delivered optimally. From all those data and analysis that has been done, we use root cause analysis to find the root cause using fault tree analysis. The results identify eleven root causes, namely, the lack of collaboration, not enough information about registration and activation process, identity verification manually (offline) through office bank, fill out the paper form and signing documents, pay for registration manually, using a browser to fill the form, lack of follow up, the proof is in pdf format, there is minimum credit to get OTP, need to register to SMS banking first and identify verification trough ATM.

\section{DISCUSSION}

\section{A. Value Co-creation and Orchestration Process}

In proposing the relevant business solution for regional bank's mobile banking to overcome the root cause, this research will use the service science framework, value cocreation, and orchestration platform. We need to identify four process phases between the customer and the provider in creating value co-creation: co-experience, co-definition, coelevation, and co-development.

In the co-experience process, customers need to understand the Regional bank's mobile banking services. In contrast, the provider needs to provide complete information about the Regional bank's mobile banking services process and easy access to experience the service. After they interact and understand each other, it will create a co-definition process. 
TABLE III: CO-EXPERIENCE AND CO-DEFINITION ACTIVITY

\begin{tabular}{|c|c|c|c|c|}
\hline \multirow{2}{*}{$\begin{array}{c}\text { Co-Experience and } \\
\text { Co-definition Activity }\end{array}$} & \multicolumn{4}{|c|}{ Detail of the program } \\
\hline & Objective & Indicator & Target & Initiatives \\
\hline $\begin{array}{l}\text { Interactive information } \\
\text { before registering or } \\
\text { activation }\end{array}$ & $\begin{array}{l}\text { To give information as detail } \\
\text { as possible regarding the } \\
\text { registration and activation } \\
\text { process in the regional bank's } \\
\text { mobile banking application }\end{array}$ & $\begin{array}{l}\text { The customer knows the } \\
\text { process of registration } \\
\text { and activation from the } \\
\text { beginning until the end }\end{array}$ & $\begin{array}{l}\text { all the customers } \\
\text { understand the process }\end{array}$ & $\begin{array}{l}\text { Creating timeline or pop-up } \\
\text { information regarding the } \\
\text { process before the customer } \\
\text { continue to the next stage }\end{array}$ \\
\hline $\begin{array}{l}\text { Step Process page on } \\
\text { regional bank's mobile } \\
\text { banking apps }\end{array}$ & $\begin{array}{l}\text { To follow up and inform the } \\
\text { customer about the current } \\
\text { step process and as a proof } \\
\text { registration station (process) }\end{array}$ & $\begin{array}{l}\text { A program has been } \\
\text { created or added to an } \\
\text { existing service system. }\end{array}$ & $\begin{array}{l}\text { All the customers who } \\
\text { registered or activated } \\
\text { mobile banking get } \\
\text { information for the } \\
\text { following step process } \\
\text { and schedule }\end{array}$ & $\begin{array}{l}\text { Preparing the notification } \\
\text { system to the customer }\end{array}$ \\
\hline $\begin{array}{l}\text { Create an active social } \\
\text { media channel }\end{array}$ & $\begin{array}{l}\text { Interaction between service } \\
\text { and provider regarding the } \\
\text { feedback, promo, discount, } \\
\text { and launching a new feature }\end{array}$ & $\begin{array}{l}\text { A program has been } \\
\text { created on major social } \\
\text { media }\end{array}$ & $\begin{array}{l}\text { Minimum has one social } \\
\text { media platform that is } \\
\text { actively used }\end{array}$ & $\begin{array}{l}\text { Preparing the resources of } \\
\text { talented administration }\end{array}$ \\
\hline
\end{tabular}

TABLE IV: CO-ELEVATION AND CO-DEVELOPMENT ACTIVITY

\begin{tabular}{|c|c|c|c|c|}
\hline \multirow{2}{*}{$\begin{array}{l}\text { Co-Elevation and Co- } \\
\text { Development Activity }\end{array}$} & \multicolumn{4}{|c|}{ Detail of the program } \\
\hline & Objective & Indicator & Target & Initiatives \\
\hline $\begin{array}{l}\text { Video call verification } \\
\text { process }\end{array}$ & $\begin{array}{l}\text { Identity verification } \\
\text { through online }\end{array}$ & $\begin{array}{l}\text { Creating service system } \\
\text { by using video call } \\
\text { process, customer don't } \\
\text { need to go to the bank }\end{array}$ & $\begin{array}{l}\text { All customers must verify } \\
\text { trough online }\end{array}$ & $\begin{array}{l}\text { With the help of current } \\
\text { customer service to do } \\
\text { online video call }\end{array}$ \\
\hline $\begin{array}{l}\text { Digitalization of the } \\
\text { requirement }\end{array}$ & $\begin{array}{l}\text { Fill out the form and } \\
\text { signing the document } \\
\text { digitally }\end{array}$ & $\begin{array}{l}\text { Creating a digital } \\
\text { database and no paper } \\
\text { and stamp needed }\end{array}$ & $\begin{array}{l}\text { All requirements of digital } \\
\text { form }\end{array}$ & $\begin{array}{l}\text { Creating a database for the } \\
\text { digitized data }\end{array}$ \\
\hline $\begin{array}{l}\text { No minimum balance for } \\
\text { registration new bank } \\
\text { account }\end{array}$ & $\begin{array}{l}\text { Provide an easier method } \\
\text { to open a bank account at } \\
\text { the beginning }\end{array}$ & $\begin{array}{l}\text { There is no transaction } \\
\text { at the beginning of the } \\
\text { opening new account }\end{array}$ & $\begin{array}{l}\text { All customers get no } \\
\text { minimum balance on their } \\
\text { account }\end{array}$ & $\begin{array}{l}\text { By re-examining the } \\
\text { minimum balance policy }\end{array}$ \\
\hline $\begin{array}{l}\text { All in regional bank's } \\
\text { mobile banking application }\end{array}$ & $\begin{array}{l}\text { Simplification of the } \\
\text { service system }\end{array}$ & $\begin{array}{l}\text { All in regional bank's } \\
\text { mobile banking } \\
\text { application no need } \\
\text { external application or } \\
\text { browser }\end{array}$ & $\begin{array}{l}\text { All subservices are } \\
\text { included in the regional } \\
\text { bank's mobile banking } \\
\text { application }\end{array}$ & $\begin{array}{l}\text { the improvement of the } \\
\text { system by IT department }\end{array}$ \\
\hline Free of OTP charge & $\begin{array}{l}\text { To minimize failure of the } \\
\text { registration and receiving } \\
\text { the OTP }\end{array}$ & $\begin{array}{l}\text { Customers will receive } \\
\text { OTP regarding the } \\
\text { amount of credit } \\
\text { number that they have }\end{array}$ & $\begin{array}{l}\text { Customers will receive } \\
\text { OTP }\end{array}$ & $\begin{array}{l}\text { By re-examining the OTP } \\
\text { charge policy }\end{array}$ \\
\hline $\begin{array}{l}\text { Directly choose } \\
\text { bank's mobile } \\
\text { activation }\end{array}$ & $\begin{array}{l}\text { Simplification of the } \\
\text { service system }\end{array}$ & $\begin{array}{l}\text { Customers can choose } \\
\text { the service and don't } \\
\text { have to take all the } \\
\text { service }\end{array}$ & $\begin{array}{l}\text { All customers can choose } \\
\text { the specific service }\end{array}$ & $\begin{array}{l}\text { By re-examining the SMS } \\
\text { and mobile banking } \\
\text { policy }\end{array}$ \\
\hline
\end{tabular}

From Table III, we can see there are three activities that have been 'co-experience' and 'co-definite' that improve some of the root causes, namely not enough information about registration and activation process by providing interactive information before registering and activation; lack of follow up; and the proof is using pdf format by providing step process page on Mobile banking application and create social media for additional information.

In Co-elevation and Co-development process, the customers expect the regional bank's Mobile banking services for the provider, and the provider provides it with their capability. So, the provider must increase their capacity so they can fulfil the expectation from the customers. To do this, the provider needs to develop or improve the system by co-development process.

From Table IV, we can see three activities that have been 'co-elevation' and 'co-development' that improve some of the root causes. The root causes are identity verification manually (offline) and through ATM change with the video call verification process. The second is to fill out the paper form and signing a document change with the digitalization of the document required. The third is to pay for registration manually change with no minimum balance needed for the beginning of the registration. Then, using a browser to fill the form change with all in a mobile banking application. After that, the minimum credit to get OTP to change with free of OTP charge. Lastly, the need to register SMS banking first change directly to choose mobile banking activation.

\section{B. Collaboration}

The classical approach to economics took the view that competition was the driving force for commercial activity. In microeconomics, industrial organization models focused on industrial structure conduct performance and showed that the more companies there were in an industry, the greater the levels of competition [29]. In this era, we need more collaboration to shared knowledge, advantage, value to others, even to our competitors, to make the pie bigger. Coopetition is a situation where competitors simultaneously cooperate and compete with each other. The primary purpose is to make the bigger pie or opportunity in the market [30]. Regional Bank's Mobile banking needs collaboration with external actors or competitors to create the Mobile banking service feature relevant and compete in the market. Below Table $\mathrm{V}$ is an explanation about the actors that need to collaborate. 
TABLE V: COLLABORATION

\begin{tabular}{|c|c|c|}
\hline Actors & When & How \\
\hline $\begin{array}{l}\text { E-commerce } \\
\text { (e.g., Tokopedia, } \\
\text { Bukalapak, Shopee) }\end{array}$ & $\begin{array}{l}\text { When does the user } \\
\text { want to top up their } \\
\text { credit in the e- } \\
\text { commerce }\end{array}$ & $\begin{array}{l}\text { By coopetition with } \\
\text { each other and } \\
\text { integrate the service } \\
\text { system }\end{array}$ \\
\hline $\begin{array}{l}\text { E-wallet } \\
\text { (e.g., Gopay, OVO, } \\
\text { Linkaja, Dana) }\end{array}$ & $\begin{array}{l}\text { When users want to } \\
\text { top up in their e- } \\
\text { money }\end{array}$ & $\begin{array}{l}\text { By coopetition with } \\
\text { each other and } \\
\text { integrate the service } \\
\text { system }\end{array}$ \\
\hline
\end{tabular}

We know that it is challenging when we collaborate with our competitors. Below Table VI is the explanation of the challenges.

Table V and VI show two collaborations needed to create value for the lack of collaboration root cause. Even though they do it their competitor, but today it has become coopetition. Those collaboration results will be added to the regional bank's Mobile banking feature as one of the payments or top-up methods.

\section{Orchestration Strategy Matrix}

These value co-creation process stages are closely tied to the different strategies, from involvement, curation, and empowerment. Involvement strategy focuses on the customer to get on co-experience and co- definition process. Curation strategy is re-examining the content and meaning of existing information and putting a new interpretation in the service system. In contrast, empowerment focuses directly on promoting and give more value to co-elevation and codevelopment stages.

The involvement strategy is to draw more customers, and potential customers, the Regional bank's Mobile banking service platform needs to attract and involve customers. From Table VII, the provider needs to make the customers understand the service from registration, activation, and utilization through interactive information in the application, social media interaction, and information. After that, the important thing is to make the service system relevant to customer needs.

To encourage more customers to use the Mobile banking service platform, the provider needs to elevate and improve the service from the customer's perspective. Customers will be willing to use and register as regional banks customers. From Table VII, the provider needs to improve the video call verification process, digitalization of the requirement, all in Mobile banking apps, can directly choose the service.

To help the customer use the mobile banking platform, each customer and provider finds the other attractive and motivated to interact. From Table VII, the provider needs some changes from No minimum balance for registration of new bank account, Free of OTP charge when the customer receives the SMS, and Development of additional top-up feature with the collaboration of the third party.

\begin{tabular}{|c|c|c|}
\hline Actors & Challenges & How can? \\
\hline $\begin{array}{l}\text { E-commerce } \\
\text { (e.g., Tokopedia, } \\
\text { Bukalapak, Shopee) }\end{array}$ & $\begin{array}{l}\text { Agreement of the } \\
\text { profit-sharing of each } \\
\text { transaction and trust }\end{array}$ & $\begin{array}{l}\text { The profit margin of } \\
\text { each transaction is } \\
\text { tiny and different } \\
\text { company culture from } \\
\text { state-own enterprise to } \\
\text { the private new } \\
\text { company }\end{array}$ \\
\hline $\begin{array}{l}\text { E-wallet } \\
\text { (e.g., Gopay, OVO, } \\
\text { Linkaja, Dana) }\end{array}$ & $\begin{array}{l}\text { Agreement of the } \\
\text { profit-sharing of each } \\
\text { transaction, trust, and } \\
\text { a direct competitor of } \\
\text { regional bank's } \\
\text { mobile banking }\end{array}$ & $\begin{array}{l}\text { The profit margin of } \\
\text { each transaction is } \\
\text { tiny, different } \\
\text { company culture from } \\
\text { state-own enterprise to } \\
\text { the private new } \\
\text { company, and } \\
\text { regional bank's } \\
\text { mobile banking is e- } \\
\text { wallet by the regional } \\
\text { bank }\end{array}$ \\
\hline
\end{tabular}

TABLE VII: COLLABORATION CHALLENGES

\begin{tabular}{|c|c|c|c|}
\hline & & \multicolumn{2}{|c|}{ Value Co-creation Process } \\
\hline & & Co-experience & Co-development \\
\hline \multirow{4}{*}{$\begin{array}{l}\text { Value } \\
\text { Orchestration } \\
\text { Strategies }\end{array}$} & Involvement & 1. Interactive information before registering or & \\
\hline & & $\begin{array}{l}\text { 2. Step process page on regional bank's mobile } \\
\text { banking apps } \\
\text { 3. Create an active social media channel }\end{array}$ & \\
\hline & Curation & & $\begin{array}{l}\text { 1.Video call verification process } \\
\text { 2. digitalization of the requirement } \\
\text { 3. All in regional bank's mobile banking application } \\
\text { 4. Directly choose regional bank's mobile banking } \\
\text { activation }\end{array}$ \\
\hline & Empowerment & & $\begin{array}{l}\text { 1. No minimum balance for registration new bank } \\
\text { account } \\
\text { 2. Free of OTP charge } \\
\text { 3. Development additional top-up feature with } \\
\text { collaboration }\end{array}$ \\
\hline
\end{tabular}

\section{Service Design}

After we get the service strategy above from involvement, curation, and empowerment strategy now, we come with the service concept of each strategy. Here the author is creating a mock-up improvement for the idea just to visualize the improvement. The author's mock-ups from the strategy above can be seen in Fig. 7-9.

The Regional bank's Mobile banking application provides information on every step of the registration and activation process and what requirements need to register or activate.
The proposed mock-up can be seen for the application in Fig. 7.

In Fig. 8 a, the Regional bank provides the information status of the registration process, which step, and the next step. This step makes the customer feel there are follow-up and clear steps. In Fig. 8 b, identity verification is done through online video calls. This feature can be integrated into the apps. 


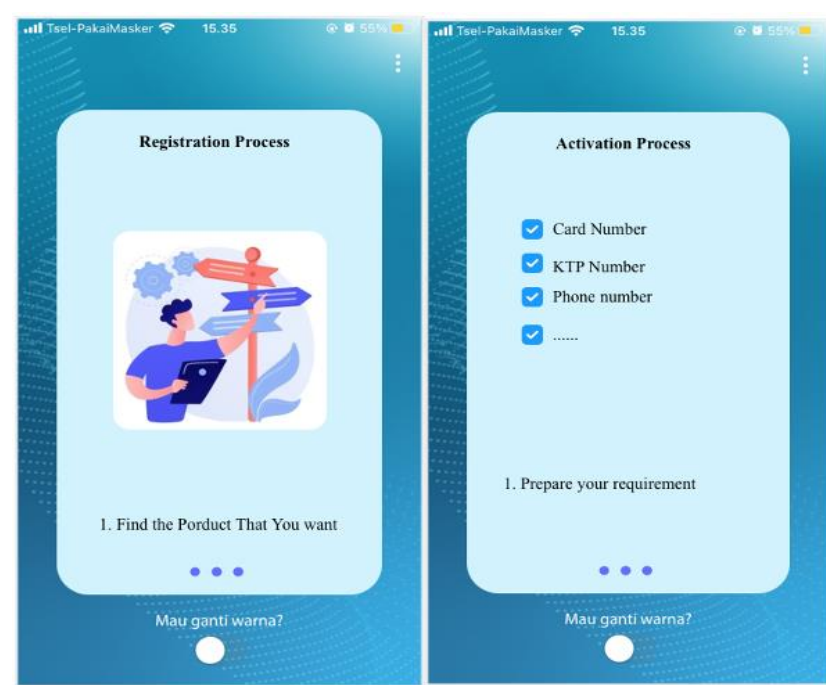

Fig. 7. Interactive information before registering or activation mock-up.

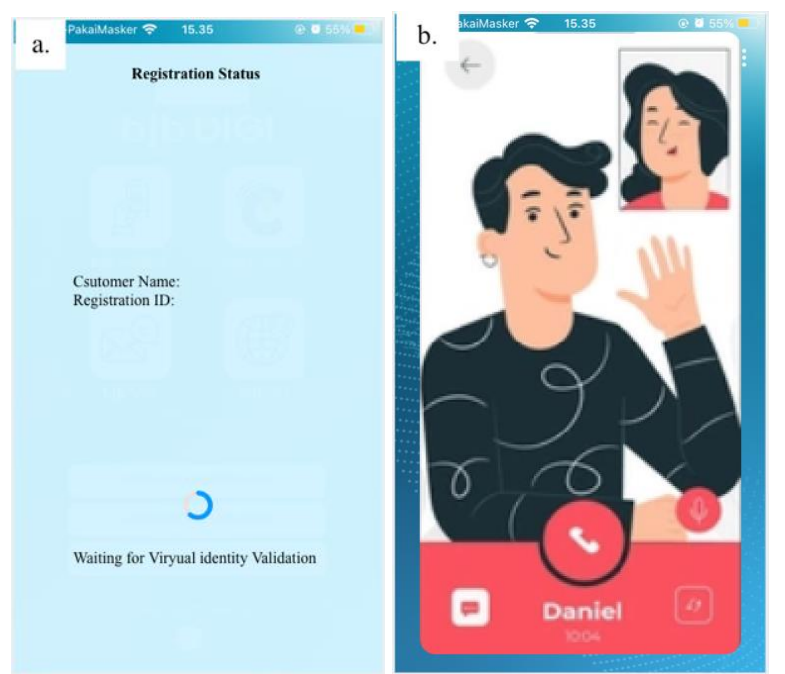

Fig. 8. a) Step process page on regional bank's mobile banking mock-up and b) video call verification process mock-up.

Fig. $9 \mathrm{a}$ is the document requirement scan process, so all the documents will be scanned to be stored digitally, and customers can do it online without having to go to the bank. In Fig. 9 b, all the registration activity happened in the regional bank's mobile banking application no longer using an external browser.

The final step of improving the regional bank's Mobile banking platform's service system is proposing a service blueprint with the improvement from findings and orchestration strategy matrix. Here, the author divided the service system into three subservices in line with the customer's three types that use the service. The first subservice is registering a new bank account, registering to the mobile banking for an existing bank account, and the last is the $\log$ in the mobile banking until end services. Below is the new proposed service blueprint.

The proposed service blueprint of the regional bank's mobile banking services from Fig. 10 to Fig. 12 improves the previous service blueprint. The improvement is from the finding and value co-creation and orchestration process. There is only one physical evidence in this service blueprint compared to the previous one, so the customer only opens the mobile banking application to get everything done in this service blueprint.

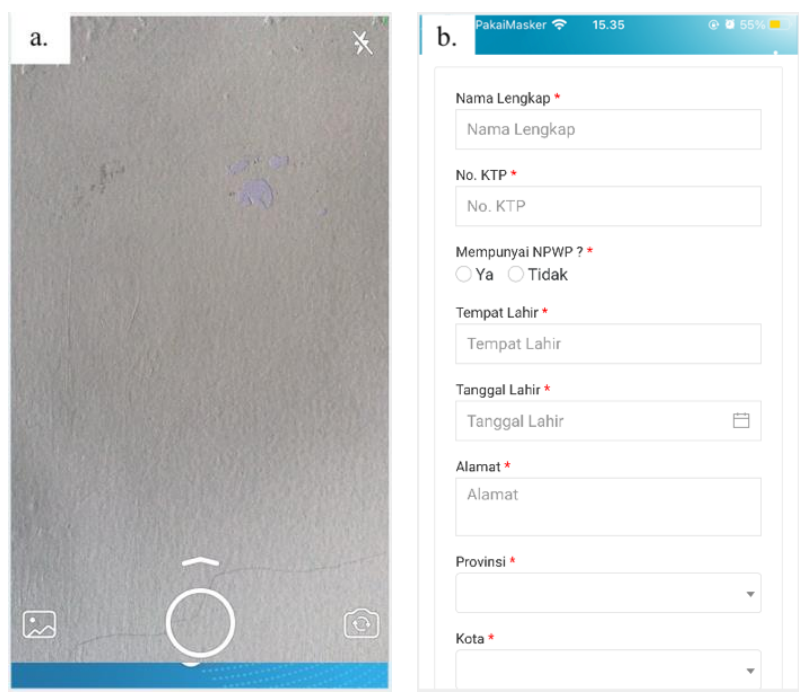

Fig. 9. a) digitalization of the requirement mock-up and b) All in regional bank's mobile banking application mock-up.

To understand the value delivered with the new proposed service blueprint, we now want to see the value delivered during all activity inside the proposed service system before using the value blueprint. Here also, the author divides the value blueprint into three subservices. The first subservice is registering a new bank account, registering to the mobile banking for an existing bank account, and the last is the log in the mobile banking until end services.

The proposed value blueprint of regional bank's mobile services from Fig. 13 until Fig. 15 is evaluated from the previous value blueprint. The improvement is from the finding and value co-creation and orchestration process. The all value from this value blueprint is a value that we want to deliver to the customer, not yet to be proof in the deal process. The system needs to be implemented first to make sure the proposed value has been provided. However, hopefully, this proposed value will be all delivered at first implementation to the system.

The proposed service system improvement for mobile banking using service science perspective is consists of value co-creation and orchestration process, service design, and service blueprint. Hopefully, by implementing such an improvement to the service system of the regional bank's mobile banking services, the service's value will be delivered to the customer after implementing all improvements. Thus, the customer need can be fulfilled by creating value cocreation by iteration each interaction of input from both customer and provider. This action is vital to the service to stay relevant to the technology, culture, customer need, economy that constantly change rapidly, especially in the digital era, society 5.0, and industry 4.0. 
European Journal of Business and Management Research www.ejbmr.org

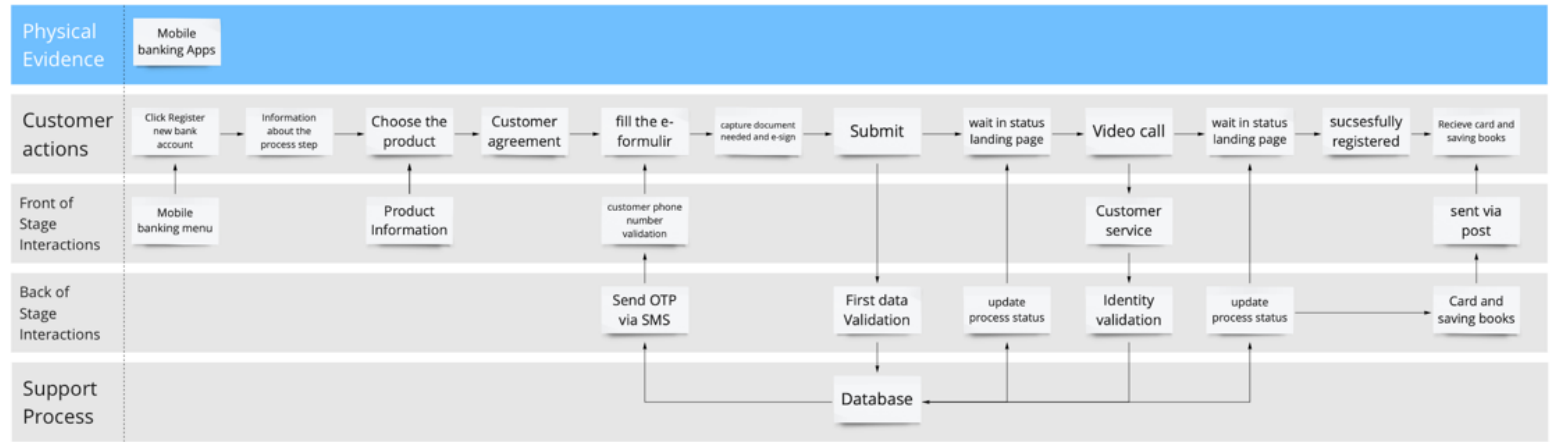

Fig. 10. Register new bank account Proposed Service Blueprint.

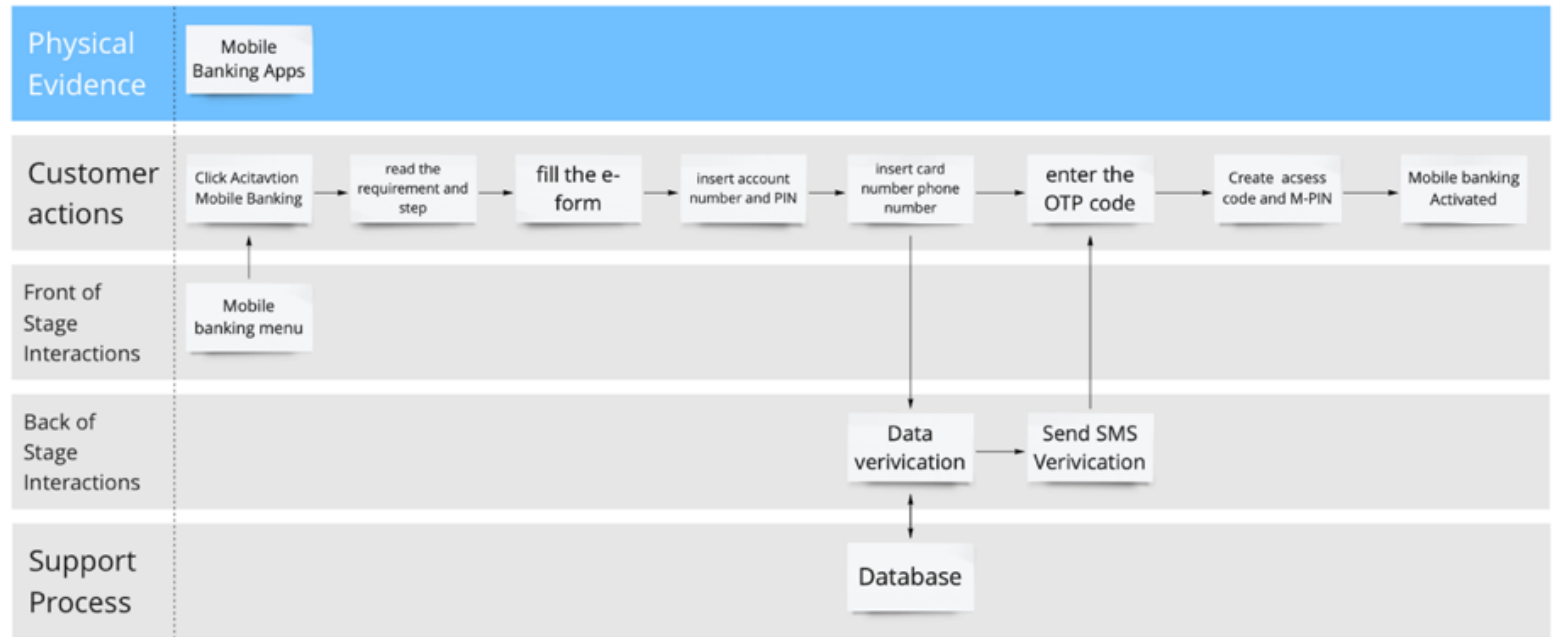

Fig. 11. Register regional bank's mobile Proposed Service Blueprint.

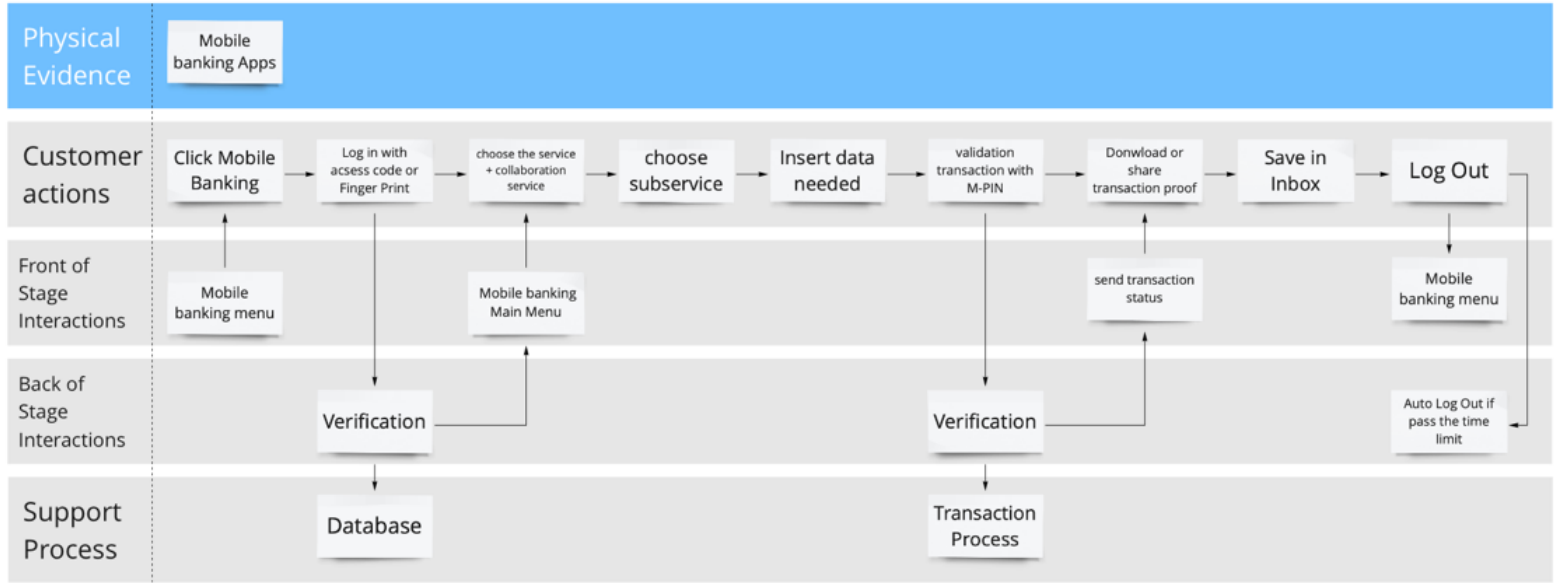

Fig. 12. Log in regional bank's mobile Proposed Service Blueprint.

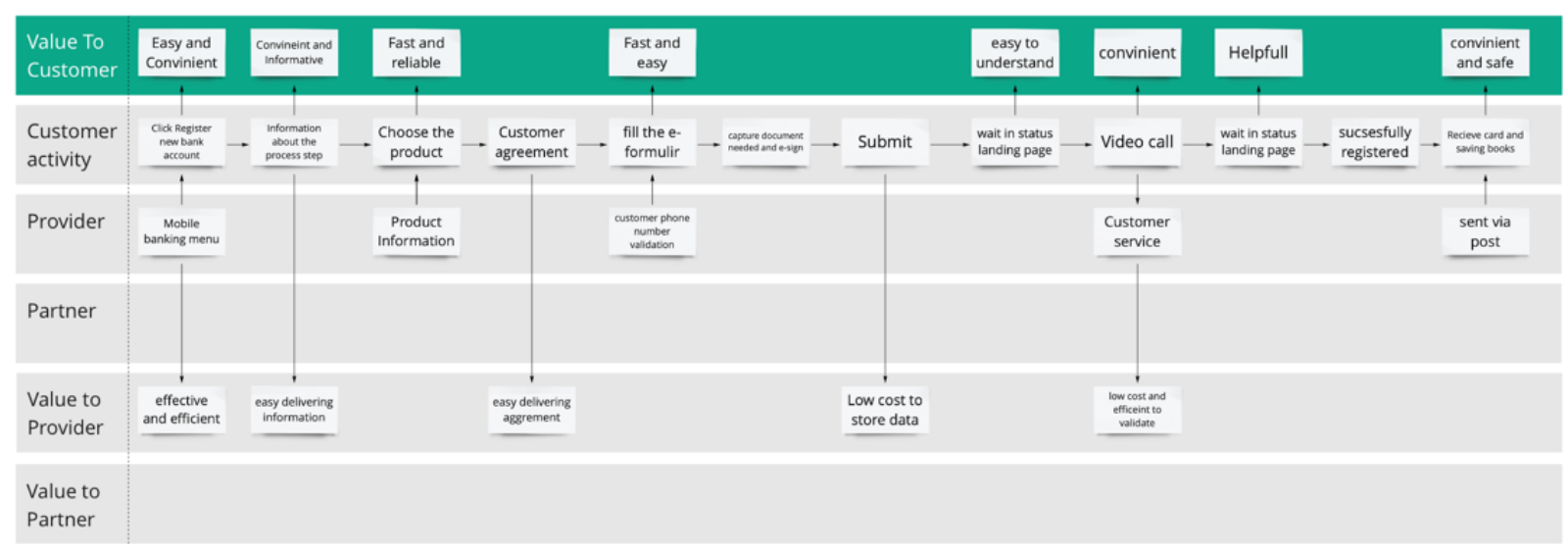

Fig. 13. Register new bank account New Value Blueprint. 


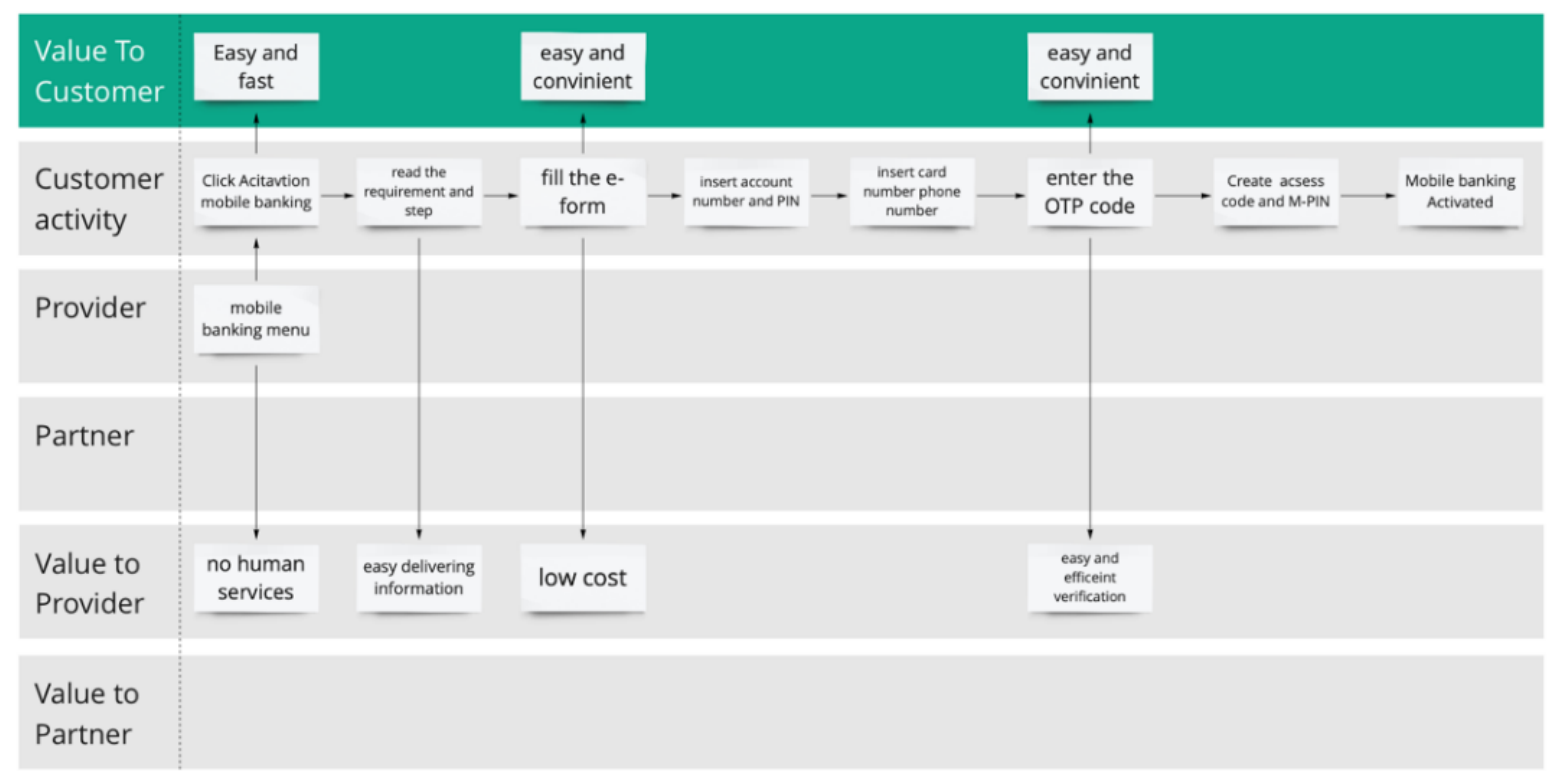

Fig. 14. Register regional bank's mobile New Value Blueprint.

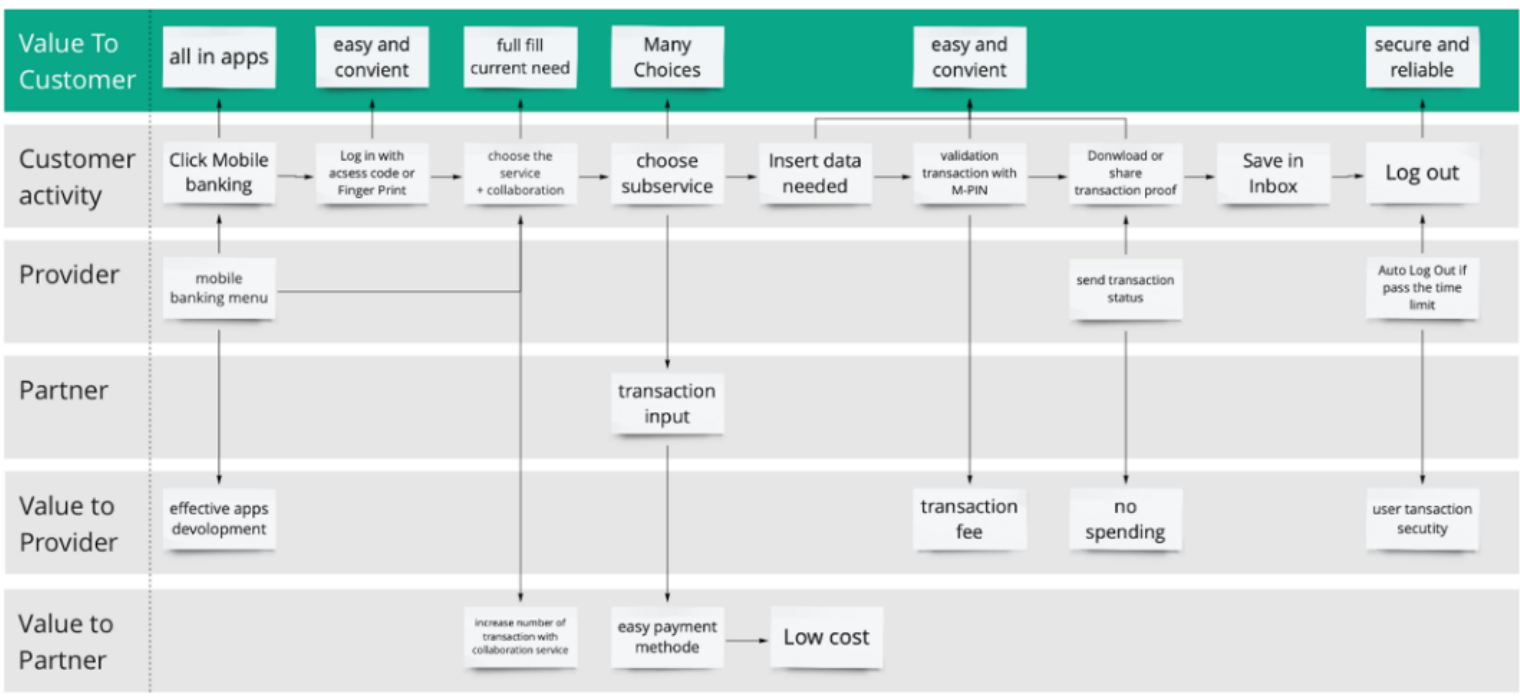

Fig. 15. Log in regional bank's Value Blueprint.

\section{CONCLUSION AND SUGGESTION}

\section{A. Conclusion}

From the research finding, the gap between the regional bank customer's wants and the service provided in their Mobile banking service mostly have come from the service system of Mobile banking. The service system is not optimal, especially in registering new accounts and activation Mobile banking. This problem because of not enough information about registration and activation process, identity verification manually (offline) through bank office, fill out the paper form and signing documents, pay for registration manually, using a browser to fill the form, lack of follow up, the proof is in pdf format, there are minimum credit to get OTP, need to register to SMS banking first and identify verification trough ATM. There is also a lack of features in Mobile banking, especially in the Top-up feature in e-commerce and e-wallet, because lack of collaboration between the provider and other parties to elaborate more about the services.

To improve the service system of the regional bank's Mobile banking service, we can use service science methods from value co-creation and orchestration process, service design, and service blueprint. The improvement is ranging from interactive information before registering or activation, step process page on the mobile banking apps, create active social media channel, video call verification process, digitalization of the requirement, all in a mobile banking application, directly choose mobile banking activation, no minimum balance for registration new bank account, free of OTP charge, and lastly the development additional top-up feature with third party collaboration. The new service blueprint has only one physical evidence (with only one mobile banking application) to get all the services. Hopefully, after the implementation, the value that the author wants will be delivered. this method can increase the convenience of the mobile banking application and contribute to increasing the number of active users and number of transactions.

\section{B. Recommendation}

The results of this research are expected to provide input for the provider and future researchers related to improving the service system in regional bank's mobile banking services. Many data used in this research, especially in a 
pandemic, can't be done right now. Also, increase the type and number of the interviewee from customer and provider from the internal data and dig deeper to increase engagement with the interviewee so the answer will be more representative of the problem in the service system. To get the best result, the author suggests that there will be research iteration about the value delivered after the implementation.

\section{REFERENCES}

[1] J. Zheng, "SARS-coV-2: An emerging coronavirus that causes a global threat," Int. J. Biol. Sci., vol. 16, no. 10, 2020, doi: 10.7150/ijbs.45053.

[2] R. Tosepu, D. S. Effendy, and L. O. A. I. Ahmad, "THE FIRST CONFIRMED CASES OF COVID-19 IN INDONESIAN CITIZENS," Public Heal. Indones., vol. 6, no. 2, 2020, doi: 10.36685/phi.v6i2.337.

[3] T. Toharudin et al., "National Vaccination and Local Intervention Impacts on COVID-19 Cases," Sustainability, vol. 13, no. 15, p. 8282, 2021, doi: 10.3390/su13158282.

[4] "Instruksi Menteri Dalam Negeri Nomor 30 Tahun 2021," Satuan Tugas Penanganan COVID-19, 2021. https://covid19.go.id/p/regulasi/instruksi-menteri-dalam-negerinomor-30-tahun-2021 (accessed Aug. 20, 2021).

[5] S. Kemp, "Digital 2021: Indonesia," Datareportal, 2021. https://datareportal.com/reports/digital-2021-indonesia?rq=indonesia (accessed Jul. 26, 2021).

[6] E. A. Eloksari, "Indonesian internet users hit 196 million, still concentrated in Java: APJII survey," The Jakarta Post, 2020. https://www.thejakartapost.com/news/2020/11/11/indonesianinternet-users-hit-196-million-still-concentrated-in-java-apjiisurvey.html (accessed Aug. 20, 2021).

[7] P. Yendamuri, G. Lim, and D. Keswakaroon, "Digital Consumers of Tomorrow, Here Today," Bain \& Company, 2020. https://www.bain.com/insights/digital-consumers-of-tomorrow-heretoday/ (accessed Aug. 20, 2021).

[8] H. Sudarsono, R. N. I. Nugrohowati, and Y. K. Tumewang, "The Effect of Covid-19 Pandemic on the Adoption of Internet Banking in Indonesia: Islamic Bank and Conventional Bank," J. Asian Financ. Econ. Bus., vol. 7, no. 11, 2020, doi: 10.13106/jafeb.2020.vol7.no11.789.

[9] C. Tam and T. Oliveira, "Literature review of mobile banking and individual performance," International Journal of Bank Marketing, vol. 35, no. 7. 2017, doi: 10.1108/IJBM-09-2015-0143.

[10] A. A. Shaikh and H. Karjaluoto, "Mobile banking adoption: A literature review," Telematics and Informatics, vol. 32, no. 1. 2015, doi: 10.1016/j.tele.2014.05.003.

[11] "Digital Disruption in Banking and its Impact on Competition," OECD, 2020. https://www.oecd.org/competition/digital-disruption-inbanking-and-its-impact-on-competition-2020.pdf (accessed Aug. 20 2021).

[12] J. Spohrer and P. P. Maglio, "The emergence of service science: Toward systematic service innovations to accelerate co-creation of value," Prod. Oper. Manag., vol. 17, no. 3, 2008, doi: 10.3401/poms.1080.0027.

[13] J. Spohrer and P. P. Maglio, "Service Science: Toward a Smarter Planet," in Introduction to Service Engineering, 2010.

[14] T. Ramadhan, D. Wibisono, R. A. Nasution, and S. Novani, "Design of Self-service Technology for Passenger Shipping Transportation Service System in Indonesia," Procedia Manuf., vol. 4, 2015, doi: 10.1016/j.promfg.2015.11.056.

[15] J. Spohrer and S. K. Kwan, "Service Science, Management, Engineering, and Design (SSMED): An Emerging Discipline - Outline \& References," Int. J. Inf. Syst. Serv. Sect., vol. 1, no. 3, 2009, doi: 10.4018/jisss.2009070101.

[16] P. P. Maglio and J. Spohrer, "Fundamentals of service science," $J$. Acad. Mark. Sci., vol. 36, no. 1, 2008, doi: 10.1007/s11747-007-0058 9.

[17] K. Kijima, "Translational and Trans-disciplinary Approach to Service Systems," in Service Systems Science, 2015, pp. 37-54.

[18] C. Grönroos, "Value co-creation in service logic: A critical analysis," Mark. Theory, vol. 11, no. 3, 2011, doi: 10.1177/1470593111408177.

[19] R. F. Lusch and S. L. Vargo, "Service-dominant logic: Reactions, reflections and refinements," Mark. Theory, vol. 6, no. 3, 2006, doi: $10.1177 / 1470593106066781$.

[20] S. Novani, U. S. Putro, and P. Hermawan, "Value Orchestration Platform: Promoting Tourism in Batik Industrial Cluster Solo," Procedia - Soc. Behav. Sci., vol. 169, 2015, doi: 10.1016/j.sbspro.2015.01.304.

[21] K. Kijima and Y. Arai, "Value Co-creation Process and Value Orchestration Platform," 2016.

[22] S. Alter, "Value blueprint and service design space for facilitating value creation," in 19th Americas Conference on Information Systems, AMCIS 2013 - Hyperconnected World: Anything, Anywhere, Anytime, 2013, vol. 5 .

[23] P. P. Maglio, S. L. Vargo, N. Caswell, and J. Spohrer, "The service system is the basic abstraction of service science," Inf. Syst. E-bus. Manag., vol. 7, no. 4 SPEC. ISS., 2009, doi: 10.1007/s10257-0080105-1.

[24] V. A. Zeithaml, M. J. Bitner, and D. D. Gremler, Services marketing: Integrating Customer Focus Across the Firm, 7th Editio. Boston: McGraw-Hill Education, 2018.

[25] M. J. Bitner, A. L. Ostrom, and F. N. Morgan, "Service blueprinting: A practical technique for service innovation," California Management Review, vol. 50, no. 3. 2008, doi: 10.2307/41166446.

[26] C. A. Ericson (II.), Fault Tree Analysis Primer. CreateSpace Independent Publishing Platform, 2011

[27] E. Ruijters and M. Stoelinga, "Fault tree analysis: A survey of the stateof-the-art in modeling, analysis and tools," Computer Science Review, vol. 15. 2015, doi: 10.1016/j.cosrev.2015.03.001.

[28] D. R. Cooper and P. S. Schindler, Business Research Methods 12th Edition. 2014.

[29] J. B. Barney, "Types of Competition and the Theory of Strategy: Toward an Integrative Framework.," Acad. Manag. Rev., vol. 11, no. 4, 1986, doi: 10.5465/amr.1986.4283938.

[30] M. Bengtsson and S. Kock, "Cooperation and competition in relationships between competitors in business networks," J. Bus. Ind. Mark., vol. 14, no. 3, 1999, doi: 10.1108/08858629910272184.

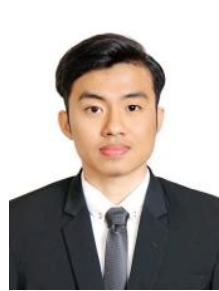

Aditya Pratama was born in Ciamis, West Java, Indonesia on Jan. 11, 1998. He graduated from Biomedical Engineering, School of Electrical Engineering and Informatics at Bandung Institute of Technology in 2019. Currently, he is pursuing a Master of Business Administration at Bandung Institute of Technology, focusing on Technology Management.

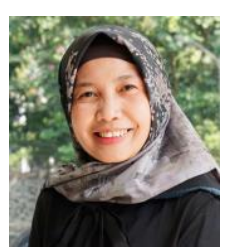

Santi Novani is an Assistant Professor at the School of Business and Management, Bandung Institute of Technology. He received his Ph.D. in service science management from Tokyo Institute of Technology, Japan, in 2013. His research interests include areas within and across service science, game theory, decision-making, multivariate statistic, and negotiation. 